\title{
Disaster Management: Tsunami and Remote Sensing Technology
}

\section{Sudhir Kumar Chaturvedi $\dagger$}

School of Engineering, UPES, Dehradun-248007, India

$†$ Corresponding author: Sudhir Kumar Chaturvedi; sudhir.chaturvedi@ddn.upes.ac.in

Nat. Env. \& Poll. Tech. Website: www.neptjournal.com

Received: 09-06-2021

Revised: $06-07-2021$

Accepted: 12-07-2021

Key Words:

Remote sensing

Tsunami

Inundation

Energy movement

Earthquakes

\section{ABSTRACT}

Remote sensing technology has changed the way disasters like earthquakes and tsunamis are detected, monitored, and mapped in recent years. This paper summarizes the general theoretical study of Tsunami generation, propagation, and its inundation for deep, intermediate, and coastal waters. Tsunami is a Japanese word, which is made up of two words: "tsu" means harbor, and "nami" means waves. It means that Tsunami is the coastal gravity waves, which propagate close to the coastline. This analysis presents a novel method to explore the effects of tsunami waves on coastal areas. The methodology includes remote sensing nearness examinations and alteration identification strategies in remote sensing to outline a number of support routes along the coast and divide them into four homogenous sub-regions. The adjustments in the land spread are then measured in these sub-regions when the tidal wave occurs. The proposed paper gives a more solid and exact method than ordinary strategies to assess spatial examples of harmful territories through various land qualities along the coastline. The generative phase of tsunami development comprises the creation of an early disruption at the surface of the ocean due to the earthquake-generated distortion on the seafloor. Various comparative studies are also carried out using spatial technology to examine tsunami routes around the globe, taking into account the most recent tsunami occurrences.

\section{INTRODUCTION}

Tsunamis are long waves, which have wavelengths order magnitude up to $10 \mathrm{~km}$ and amplitude order of $1 \mathrm{~m}$ in Ocean, where the travel velocity is of $700-800 \mathrm{~km} /$ hour. (Arii et al. 2014). Tsunamis are a dangerous threat that has no warning, cannot be predicted, and result in significant casualties and loss of life (Fig. 1).

The main cause of the Tsunami is underwater plate tectonics movements (Bryant 2001, Craig \& Sulem 1993). Tsunami waves are similar to normal waves that propagate close to the surface. The geostrophic surface current streamlining for the Indian coastline region is shown in Fig. 2 (Dean \& Dalrymple 1984).

Bottom pressure sensors can sense a tsunami of a few meters' fluctuations in the open sea (Dean 1986, Eze \& Uko 2000) as shown in Fig. 3. The tectonic plate boundaries for convergent, divergent, and transform regions are also shown in the image.

The initial displacements of the free surface of various water wave conditions are induced by a strong earthquake with a magnitude greater than 9.0 on the Richter scale, in which the creation of N-type waves is more abundant. (Fig. 4).

In 1979, experts suggested that radars can be used to distinguish tsunamis based on their orbital wave speed as they approached the coast. The scattering of radars around the globe was scanty until the 1990s. In spite of the fact that there were no radars set up to see that occasion, work started to evaluate the radar tidal wave reaction. Numerous HF radars around the Pacific Rim with clear outcomes saw the Japan tidal wave signal from locations in Japan, the USA, and Chile. The 2012 Indonesia tidal wave and the 2013 US East Coast meteotsunami were two other weak tidal waves that were seen. An experimental strategy for the programmed discovery of a wave has been created. Over $350 \mathrm{HF}$ radar sites located along the coast provide a consistent estimate of surface momentum speeds and waves. The basic model of tidal wave location programming can provide a warning before the wave reaches the coast.

\section{Remote Sensing Technology for Tsunami Signal Estimation}

The seismic detection of an earthquake could be the most visible sign of a tidal wave. Nonetheless, not all subsea seismic tremors produce tidal waves, and thus the size of a quake cannot be used to conjecture the definite age or force of a subsequent tidal wave. DART systems are designed to sense pressure changes at the bottom of the ocean caused by passing tsunamis and to communicate these changes to the tsunami warning centers. Each DART system consists 
of a bottom pressure recorder anchored to the ocean floor and a separately moored companion surface buoy. Because this system is located in the deep sea, DART (Deep-ocean Assessment and Reporting of Tsunamis) cannot detect all tidal waves, hence they are not included in the model before the beachfront effect. High frequency (HF) radar systems measure the speed and direction of ocean surface currents in near real-time The main problem with the buoy stations is that they are hard and expensive to maintain, and because they are located in a rather harsh environment, they have a fairly high failure rate. These radars can measure currents over a large region of the coastal ocean, from a few kilometers offshore up to $200 \mathrm{~km}$, and can operate under any weather conditions. They are located near the water's edge, and need not be situated atop a high point of land. These radars, show the exact wave location that can otherwise be missed out. This can detect and warn of approaching tidal waves in the nearby shore district where these radars monitor the ocean surface. A sum of 21 disconnected radar discoveries of waves has been made to date. Tsunami periods lie normally somewhere in the range of 20 and $50 \mathrm{~min}$. A tidal wave starts when there is a huge removal of water: The spatial sizes of water dislodging are as a rule of extraordinary even however little vertical measurements These include subsea seismic

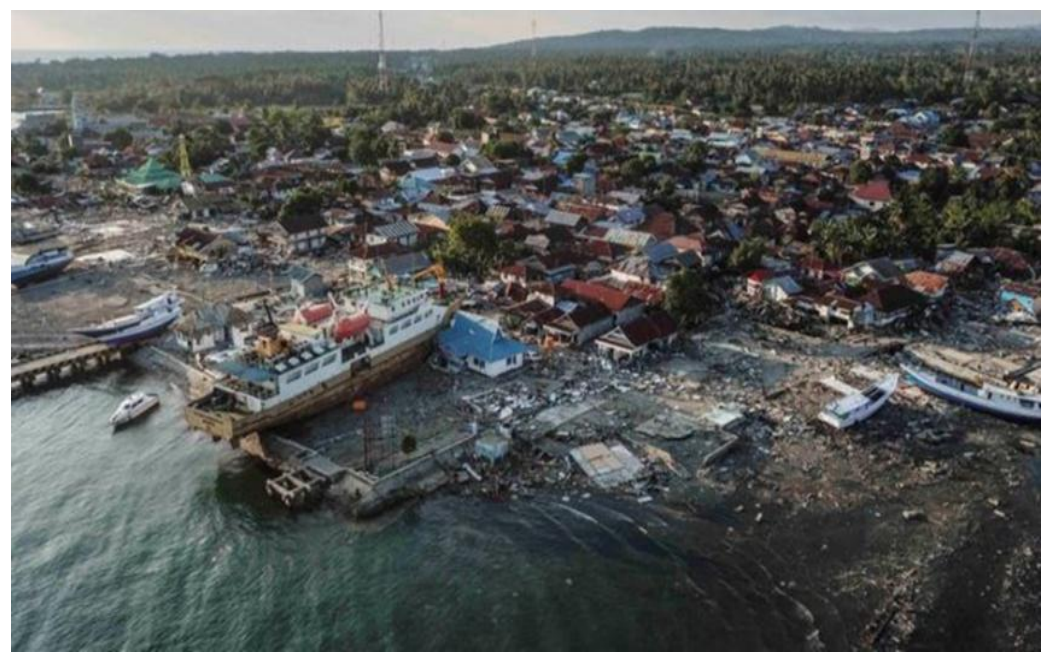

Fig. 1: An aerial photo of the devastation in the Dongola area, north of Palou (Image source: BBC).

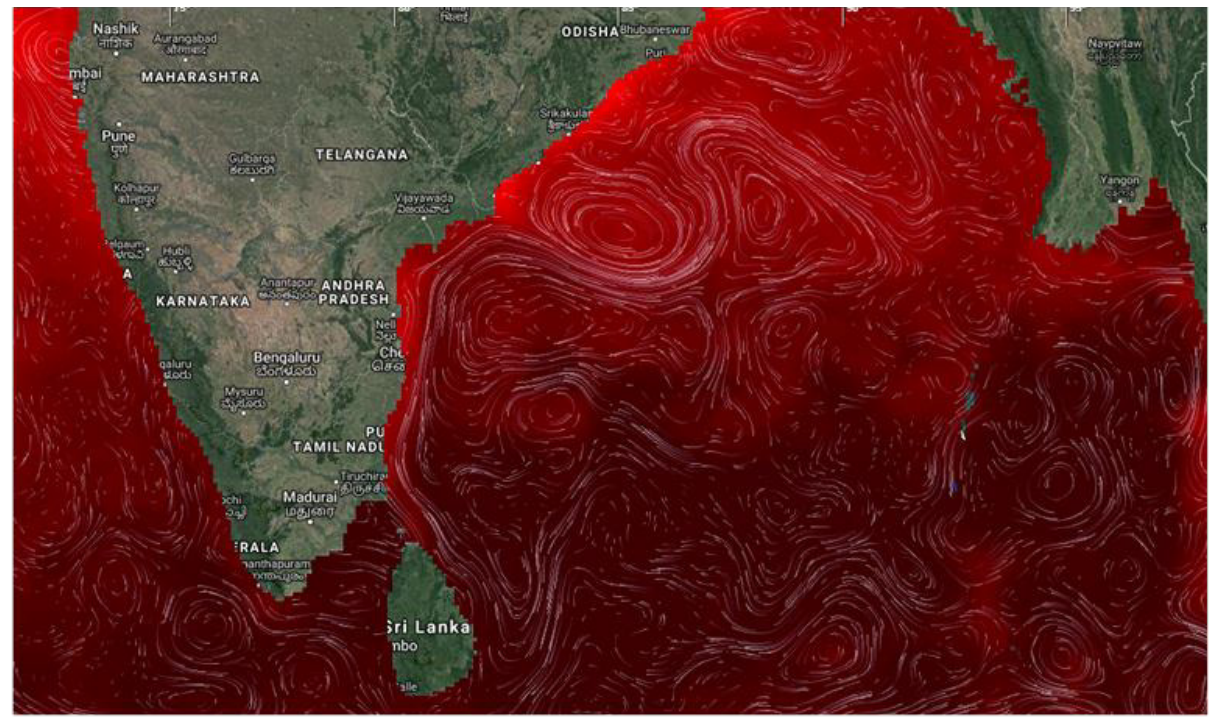

Fig. 2: Geostrophic surface current streamline (Glob current) of Indian coastal region (Source: ESA Ocean virtual laboratory). 


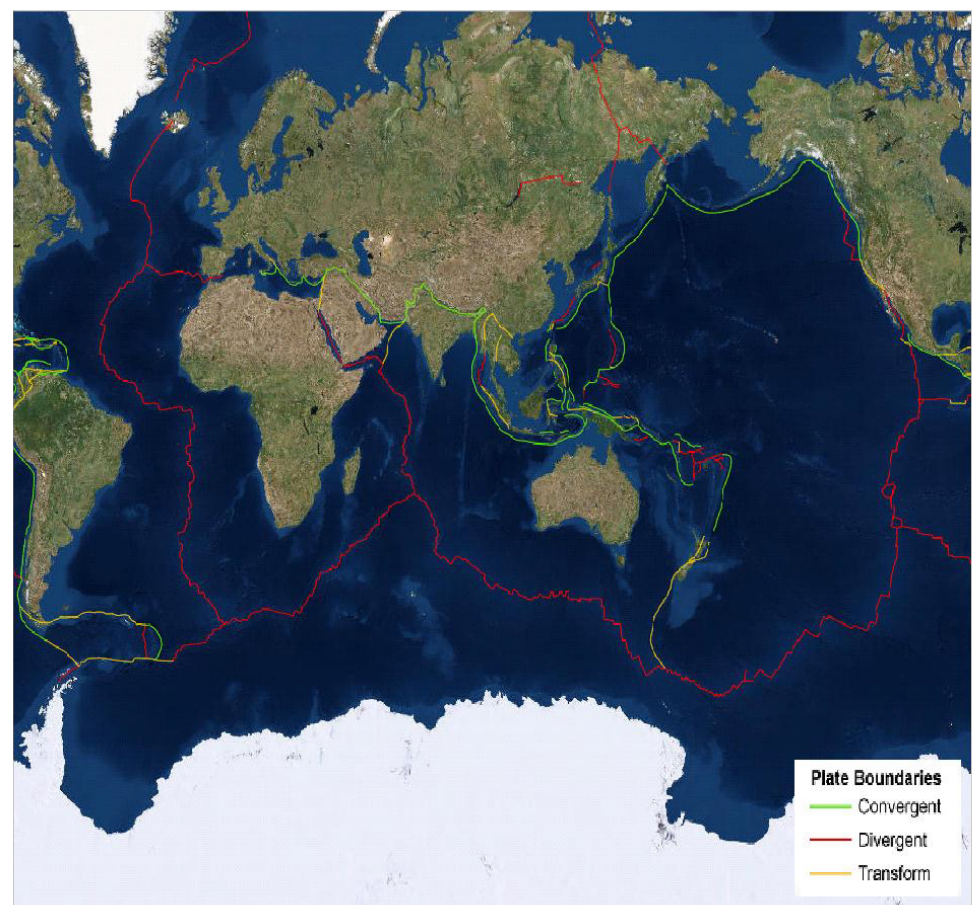

Fig.3: Tsunami plate boundaries (Source: NOAA National Centers for Environmental Information, Natural Hazards Viewer).

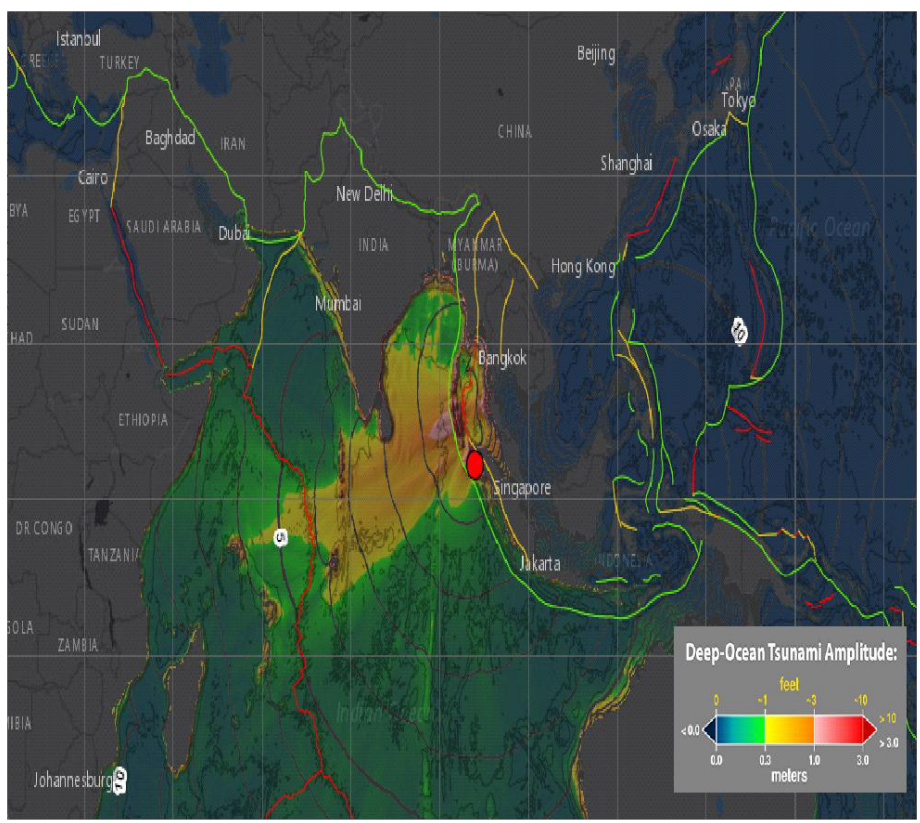

Fig. 4: Sumatra, Indonesia tsunami impact on 26th December 2004 (Source: NOAA National Centers for Environmental Information, Natural Hazards Viewer).

tremors where plates drive each other upward/descending, separately; subsea avalanches along soak submerged uneven slants; or quick-moving environmental inconsistencies (for example low-pressure focuses) that make "meteotsunami." The origins can be hundreds of kilometers away or very close to an impacted beachfront territory (where an HF radar may be located). As the dislodged water mass leaves its source area affected by gravity, it turns into a shallow-water wave. Tidal waves are shallow-water waves stretching out far into the ocean and continuously changing the ebb and flow pat- 
terns. We describe a method for predicting tidal wave arrival at a coastline based on the projected speed of a simulated tidal wave. The factors that influence the radar location of tidal waves are discussed. The difficulties that can occur in wave detection, as well as reduction methods, are depicted.

Tsunamis are members of the same family as normal sea waves, which can be seen from a distance near beaches. The majority of big tsunamis have been caused by undersea earthquakes. The sudden displacement of the ocean surface is caused by spontaneous seafloor movement. By restoring gravitational forces, the sudden gain in potential energy is transferred to kinetic energy. The characteristics of tsunamis in the four oceans are detailed in Table 1 below.

Currently, ocean floor pressure sensors in the open sea may detect a tsunami of a few centimeters in height. To determine whether the tsunami was indeed formed, the tsunami

Table 1: Characteristics of Tsunami for the 4 oceans (Source: NOAA National Centers for Environmental Information).

\begin{tabular}{|c|c|c|c|c|}
\hline Parameter & Pacific Ocean & Atlantic Ocean & Indian Ocean & Arctic Ocean \\
\hline Area $\left(\mathrm{km}^{2}\right)$ & $166,241,000$ & $86,557,000$ & $73,427,000$ & $9,485,000$ \\
\hline Average depth (m) & 4188 & 3735 & 3872 & 1038 \\
\hline Deepest point (m) & $\begin{array}{l}\text { Mariana Trench, } \\
11,033\end{array}$ & $\begin{array}{l}\text { Puerto Rico Trench, } \\
8648\end{array}$ & Java Trench, 7725 & Eurasian Basin, 5450 \\
\hline Number of trenches & 18 & 3 & 1 & None \\
\hline $\begin{array}{l}\text { Unpopulated area }(\%) \text { - Southern } \\
\text { Ocean }\end{array}$ & $\sim 20$ & 30 & 55 & Almost all of it \\
\hline $\begin{array}{l}\text { Length scale available }(\mathrm{km}) \text {. Half } \\
\text { the size of an equivalent (in the area) } \\
\text { square }\end{array}$ & 6447 & 4642 & $\begin{array}{l}4284 \text {; if we omit the } \\
\text { unpopulated area, it is } \\
\text { about } 2000\end{array}$ & 1540 \\
\hline Ocean-wide tsunamis & Yes & No & Yes & $\begin{array}{l}\text { Rare - extremely strong } \\
\text { dissipative influence by ice } \\
\text { cover }\end{array}$ \\
\hline $\begin{array}{l}\text { Tectonic-converging plates producing } \\
\text { tsunami genic earthquakes }\end{array}$ & Yes & $\begin{array}{l}\text { No; at the mid-Atlantic } \\
\text { ridge, the plates are di- } \\
\text { verging }\end{array}$ & Yes & $\begin{array}{l}\text { Some, but not as strong } \\
\text { as in the Pacific and Indian } \\
\text { oceans }\end{array}$ \\
\hline Frequency of tsunami occurrence & High & Rare & Rare & Rare \\
\hline Frequency dispersion & High & $\begin{array}{l}\text { N/A - since no } \\
\text { ocean-wide tsunamis }\end{array}$ & Low & Small \\
\hline $\begin{array}{l}\text { Amplitude dispersion (nonlinear } \\
\text { effects at the coast) }\end{array}$ & High & High & High & $\begin{array}{l}\text { Moderate; ice cover does not } \\
\text { permit significant amplification } \\
\text { of tsunami waves at the coast }\end{array}$ \\
\hline Tsunami travel times & Up to $23 \mathrm{~h}$ & $\begin{array}{l}\text { Only local tsunamis } \\
\text { which travel within } \\
\text { minutes }\end{array}$ & $\begin{array}{l}\text { Up to } 10 \mathrm{~h} \text { to the most } \\
\text { populated area }\end{array}$ & $\begin{array}{l}\text { Local tsunamis; several min- } \\
\text { utes to almost a couple of hours }\end{array}$ \\
\hline $\begin{array}{l}\text { Available warning time to most pop- } \\
\text { ulated areas }\end{array}$ & $\begin{array}{l}\text { Generally suffi- } \\
\text { cient }\end{array}$ & $\begin{array}{l}\text { Because of local tsuna- } \\
\text { mis, only several min- } \\
\text { utes }\end{array}$ & 1 to $4 \mathrm{~h}$ & Small - mostly several minutes \\
\hline Importance of initial conditions & High & High & High & High \\
\hline Importance of boundary reflections & Low & $\begin{array}{l}\text { Low, since tsunamis } \\
\text { originate close } \\
\text { to the coast }\end{array}$ & High & $\begin{array}{l}\text { Moderate; ice cover does not } \\
\text { allow significant wave's re- } \\
\text { flection }\end{array}$ \\
\hline Boundary conditions & Low & Medium & High & Medium \\
\hline Coriolis force & Noticeable & Highly & Moderate & High \\
\hline Nature of physical process & $\begin{array}{l}\text { H y p e r b o } 1 \text { i c } \\
\text { (like astrology): } \\
\text { everything is de- } \\
\text { termined at birth }\end{array}$ & $\begin{array}{l}\text { Parabolic: tsunamis } \\
\text { travel slowly in shallow } \\
\text { water near the coast. It } \\
\text { is like a slow diffusion } \\
\text { process }\end{array}$ & $\begin{array}{l}\text { Elliptic: tsunami behav- } \\
\text { ior everywhere in the } \\
\text { ocean, including reflec- } \\
\text { tions at the boundaries, is } \\
\text { relevant everywhere else }\end{array}$ & $\begin{array}{l}\text { Halfway between parabolic } \\
\text { and elliptic }\end{array}$ \\
\hline
\end{tabular}


wave indicators are first based on the number of seismic tremors such as magnitude, sea depth, and location. A tsunami is a series of ocean gravitational waves that form as a result of large-scale disturbance of the seabed (Josheph 2010, Kânoglu \& Synolakis 1998, Liu et al.1995). The Boussinesq equation is proposed as a tool for studying tsunami wave formation, dispersion, and run-up. The movement of a tsunami in the sea differs from that of other waves because it happens throughout the entire water column, from the surface to the ocean bottom. This phenomenon causes a tsunami to take on the shape of a solitary wave in shallow water. Little energy is dissipated because the wave's motion involves the entire water column, especially on steep coasts (Lin et al. 2013)

A tsunami wave motion distribution can be studied by examining the eigen functions with respect to depth variation at a given angular frequency. The values of the orbital velocity and distribution varied from the deep ocean to the coastal regions. In terms of their mode of generation, propagation, wavelength, time period, velocity, and distribution of the oceanic region to the coastal parts of the particular region, tsunamis are characterized differently (Madsen \& Schäffer 2010). Hence, tsunamis have different consequences than normal wave propagation. Surface disturbances caused by seafloor movements can be examined using various analyses and mathematical models such as potential theory, power series Laplace Transform solutions, and Fourier Laplace Transforms for linear problems. The Boussinesq model results have shown excellent linear and non-linear properties, such as linear dispersion, shoaling, subharmonics, and super harmonics transmissions (Filloux 1970)
The generation stage of the tsunami includes the formation and evolution of initial ocean surface displacements due to the large earthquake triggered at the bottom of the seafloor. The generated water surface is transformed to the long gravity waves, which radiate from the earthquake source where it occurred at the time of evolution. The modeling of the tsunami is carefully related to further readings on the earthquake tools (Geist 1998)

The usefulness of early detection and warning systems has been demonstrated, particularly in the aftermath of the devastating tsunami that struck Japan in March 2011, as shown in Fig. 5. The objective of this study is to update and improve existing tsunami results to improve detection and early warning prediction accuracy (Okal 1988).

In this study, two major tasks have been carried out: (1) To calculate wave parameters, particularly Eigen functions (water wave number, angular frequency, horizontal and vertical orbital velocity, and acceleration, celerity of the waves) (2) Using radar data processing with q-factor estimation, the idea of an early warning system was developed. Since the work is primarily concerned with the development of radar remote sensing techniques for naval applications in tsunami detection and investigation of its early warning using radar technologies, the designed system may further be said as Integrated Tsunami Warning System (ITWS) (Martino et al. 2009)

Tsunami Modeling: Several models are currently used around the world for calculating stationary sea bottom distortions to calculate tsunami basic parameters. As a tool

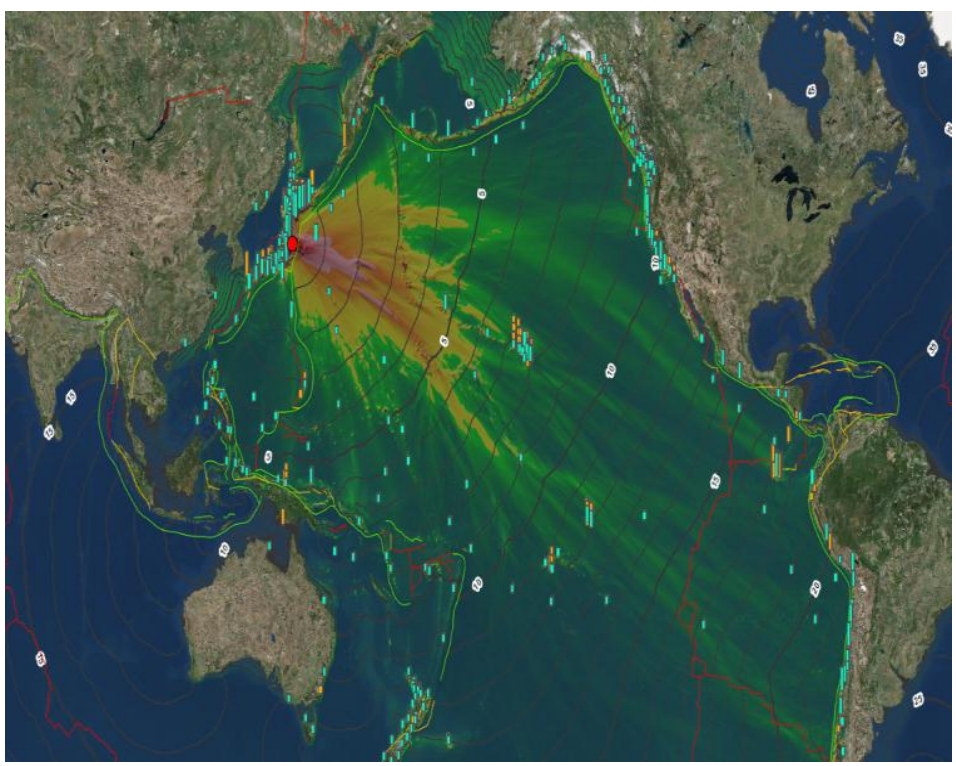

Fig.5: Tohoku-Japan tsunami impact on 11th March 2011 (Source: NOAA National Centers for Environmental Information, Natural Hazards Viewer). 
for planning calamity relief and management strategies, numerical modeling of approaching tsunamis is considered essential since the information from previous tsunamis can be insufficient for planning either relief or management of a tsunami approaching from a regional or remote area. Models are digitized to account for any unfavorable conditions for tsunami origin/waves exactly offshore to determine the related impact on neighboring island shores (Murty et al. 2006). Models might even be computed with tiny origins to know the acerbity of disaster for lesser intense but more persistent events. This data then transforms the foundation to create tsunami drainage maps and methodologies.

Modeling techniques that have recently emerged need accurate inputs of bathymetry and topographic data for the modeled area/site (Prins 1958). Several numerical tools have been utilized to communicate tsunamis to distanced islands. For example, many numerical tools have been used to communicate the propagation of tsunamis among islands over long distances (Fig. 6) (Sirikulchayanon et al. 2005)

The accuracy of model predictions is directly related to the quality of the data used to create the bathymetry and topography of the model area. Coastal Bathymetry is the prime determinant of the height of the tsunami wave or storm surge as it approaches the coast (Tadepalli \& Synolakis 1994,1996). High-resolution coastal bathymetry is thus the key input for various tsunami and storm surge prediction models. Bathymetric data provided by the National Hydrographic Office (NHO) has been used in tsunami modeling. In addition, the bathymetric survey is conducted for a few vulnerable areas of the Indian coast. CARTOSAT- 1 data is being used for generating a Digital Elevation Model (DEM) of the coastal region. Tsunami Modeling is classified into three stages: (i) generation, (ii) propagation (iii) run-up (Inundation). The guidelines and varieties of models engaged at
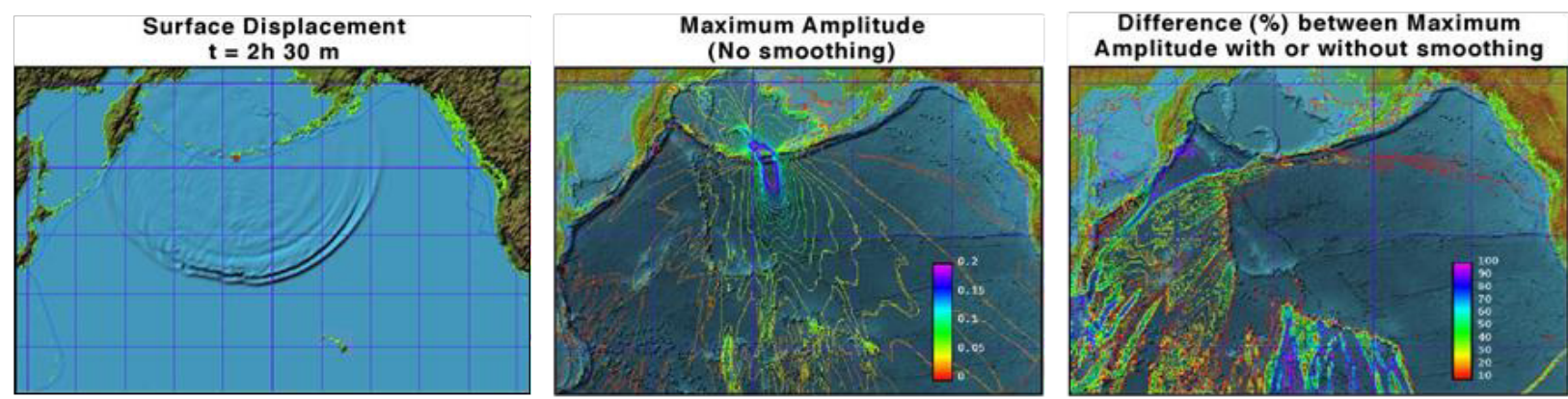

June 10, 1996 Andrean of Is. T sunami (MW = 7.7)

Epicenter at 50.60N, 177.70W

Fig. 6: Tsunami model simulation (Source: NOAA Centre for Tsunami Research).

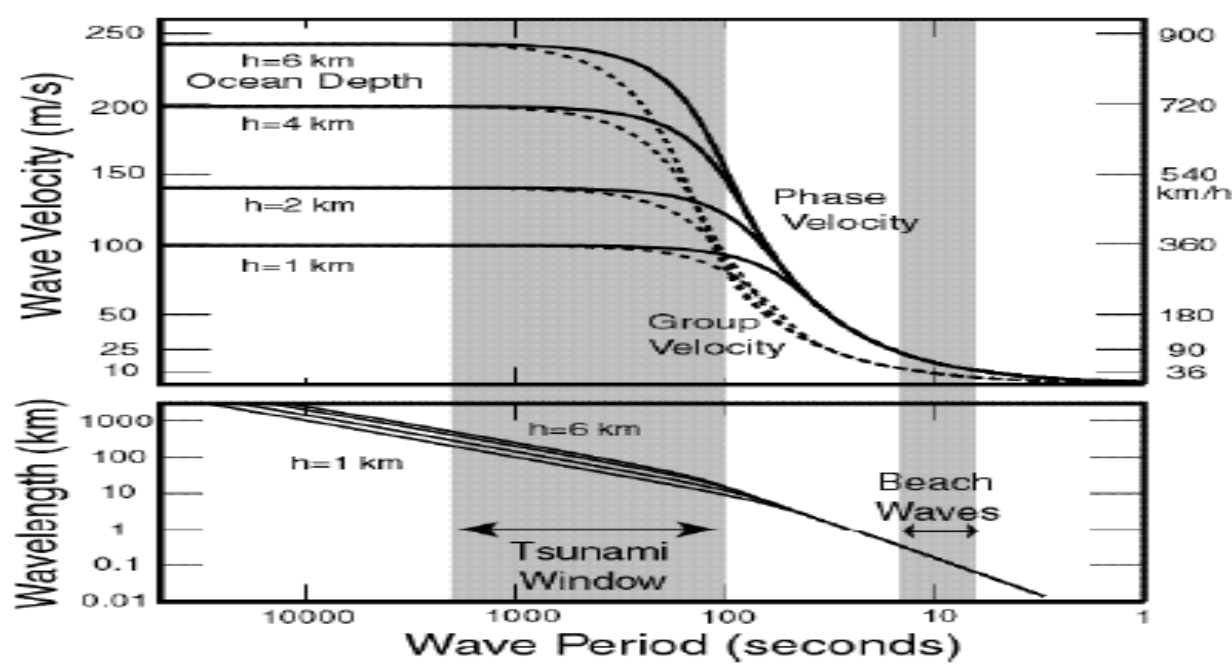

Fig. 7: (a) solid line indicates the phase velocity and dashed line represents group velocity of tsunami waves in the ocean for various depths of $1,2,4$, and $6 \mathrm{~km}$ depth, (b) shows the variation of wavelength with wave period, tsunami windows appeared (Dean 1986). 
these stages vary and depend on experimental site parameters (Titov 2000). The generation phase of tsunami comprises an early disruption at the surface of the ocean due to the earthquake-generated distortion on the seafloor. The long gravity wave searing from the earthquake's source causes this early water surface disturbance. The early phase of the tsunami's undulation is carefully modeled using several earthquake tools (Todorovska \& Trifunac 2001, Ward 1980, Zielinski \& Saxena 1983).

\section{CHARACTERISTICS OF TSUNAMIS}

Tsunamis are defined by the wave dispersion theory, which envisions a hard seafloor overlain by an incompressible, homogeneous, and non-viscous ocean that is always subjected to a constant gravitational field. The effect of frequency dispersion is that the waves travel as a function of wavelength so that spatial and temporal phase properties of the propagating wave are constantly changing. The more specific variation in the water wave frequency with the wavelength charecterstics are mentioned in Fig. 7.Tsunami wave flow from Deep to intermediate and then to coastal (shallower) regions are shown in Fig. 8.

For example, under the action of gravity, water waves with a longer wavelength travel faster than those with a shorter wavelength. As per the theory (Dean 1980), the velocity $c$, and group velocity $u$ of the gravity waves with the uniform ocean depth of $d$ are

and

$$
c=\sqrt{\frac{g h \tanh (k d)}{k d}}
$$

$$
u=c\left[\frac{1}{2}+\frac{(k d)}{\sin (2 k d)}\right]
$$

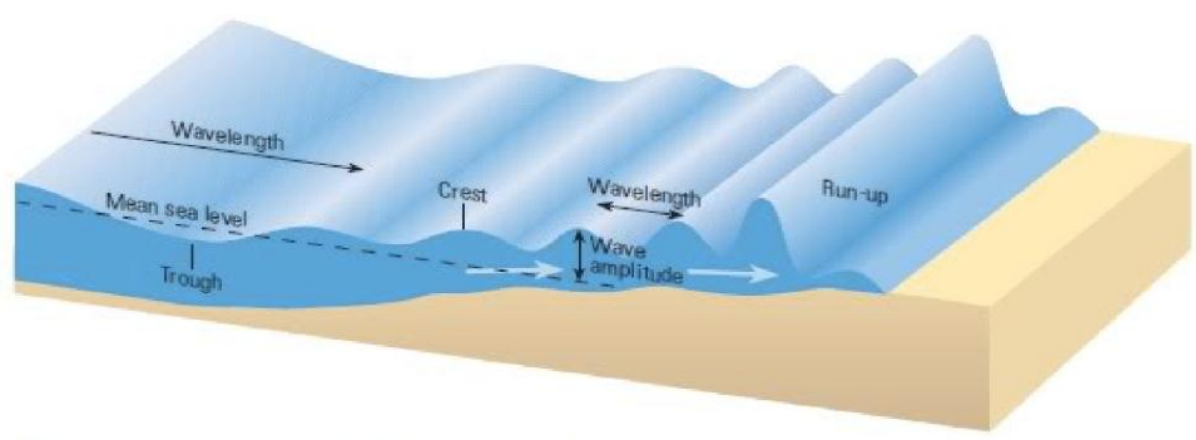

Fig. 8: Tsunami shoaling from deep to coastal region (Ward 1980).

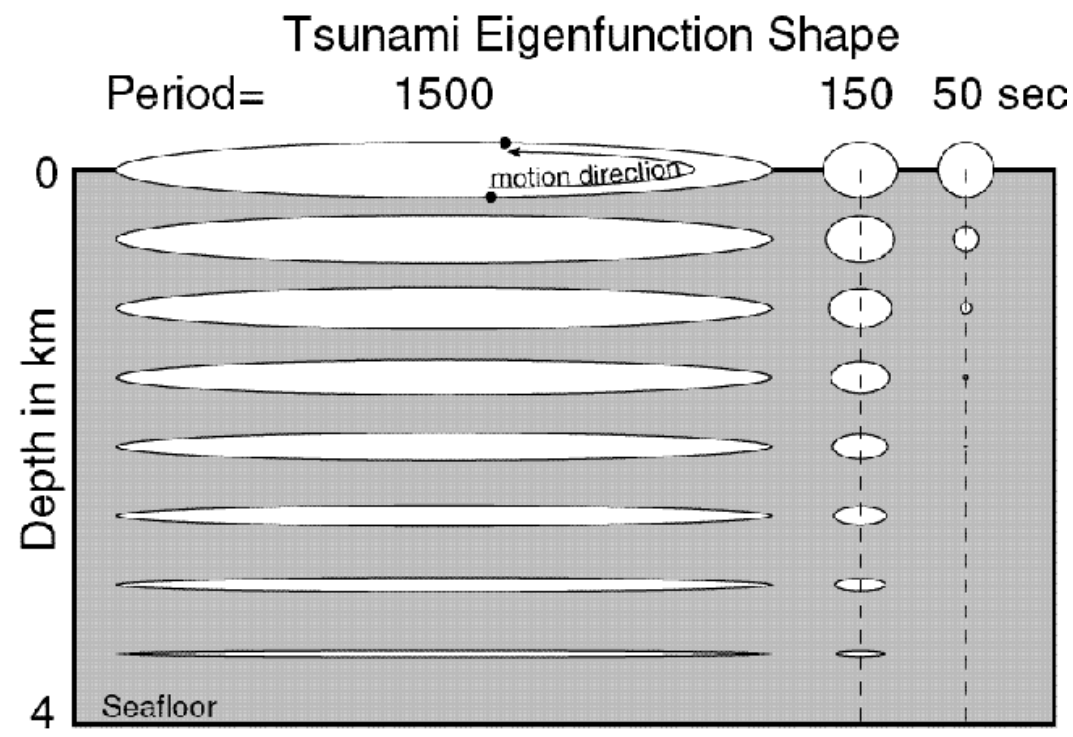

Fig. 9: Tsunami parameters (eigenfunctions) in various water depths with $1500 \mathrm{~s}, 150 \mathrm{~s}$, and 50s of time duration. 
Here, $g$ is the acceleration due to gravity and $k$ is the wave number associated with the sea wave of frequency $\omega$. Wave number correlated with the wavelength is given by

$$
L=\frac{2 \pi}{k}
$$

Wave number also satisfies the dispersion relationship, the basic and important equation used in the study of wave hydrodynamics especially to analyze the various type of waves and is given as

$$
\omega^{2}=g k \tanh (k d)
$$

\section{TSUNAMI EIGEN FUNCTIONS}

Consider a coordinate system $(x, y, z)$. Vertical $\left(u_{z}\right)$ and horizontal $\left(u_{x}\right)$ components of tsunami Eigen functions normalized to unit vertical displacement at the sea surface are (Chaturvedi et al. 2016)

$$
\begin{gathered}
u_{z}(\omega, z)=\frac{k g}{\omega^{2}} \frac{\sinh [\hat{k}(d-z)]}{\cosh [k d]} e^{i[k x-\omega t]} \\
u_{z}(\omega, z)=\frac{k g}{\omega^{2}} \frac{\sinh [k(d-z)]}{\cosh [k d]} e^{i[k x-\omega t]} \\
u_{z}(\omega, z)=\frac{-i k g}{\omega^{2}} \frac{\cosh [k(d-z)]}{\cosh [k d]} e^{i[k x-\omega t]} \\
u_{z}(\omega, z)=\frac{-i k g}{\omega^{2}} \frac{\cosh [k(d-z)]}{\cosh [k d]} e^{i[k x-\omega t]}
\end{gathered}
$$

Fig. 9 indicates the tsunami Eigenfunctions versus depth in a $4 \mathrm{~km}$ deep ocean at long (the $1500 \mathrm{~s}$ ), intermediate $(150 \mathrm{~s})$, and short (50s) periods. The little ellipses can be thought of as tracing the path of a water particle as a wave of frequency $\omega$ passes. In the 1500 s period, the tsunami has a wavelength of $L=297 \mathrm{~km}$ and it acts like a long wave (Chaturvedi et al. 2017). The vertical displacement peaks at the ocean surface and drops to zero at the seafloor. The horizontal displacement is constant through the ocean column and exceeds the vertical component by more than a factor of ten. The measurement and validation of the wave parameters are provided by Chaturvedi et al. 2019, 2020 for deep, intermediate, and shallower regions.

\section{COMPARATIVE STUDY ON RECENT TSUNAMIS ACROSS THE GLOBE}

The results introduced for each location are merged in the following in a way that allows for future estimation of territorial tidal wave risk. A solitary wave risk map is created using this process by adding all of the extreme sea levels for each of the individual tidal wave occurrences. Only a few territories appear to be effectively protected against tidal waves (Fig. $10 \& 11$ ). Furthermore, it is concentrated in select areas, such as eastern Halmahera and the Makassar Strait; the combined hazard map is unlikely to include much of the risk (Helm \& Stosius 2007, Chatterjee et al. 2008). A tidal wave may impact stretches of the coastline near the origins only a few minutes after it is generated, giving only a few minutes' notice and putting many inhabited areas at risk.

Tidal wave risks, in most parts, can be reduced or eliminated using predefined building construction plans. The guideline necessitates that buildings must be constructed within these areas, which must be evaluated to determine whether a risk exists in the area. If this is the case, major structural modifications must be undertaken before permission for private construction can be granted.

The simulation model in the study shows that significant stretches of the coastlines are subjected to extreme water levels in the range of 2-4 m, and at times exceeding $10 \mathrm{~m}$. (Fig. 11). The wave metric (extreme water level) must be combined with the transient possibility of the situation to measure the risk, despite the fact that extreme water levels represent a high risk. (Westen \& Soeters 2009)

Recent Tsunami registered datasets with UTC zones are also given in Table

Fig. 12 shows Tsunami events elaboration with symbols for cause or fatalities

The combination of broad immersion potential, short warning periods, and fairly short return times strongly suggests that the current hazards in these areas are disturbing; this could also indicate that the hazard is alarmingly high. This calls for prompt and coordinated activities needed for reducing the tsunami hazard.

\section{CONCLUSIONS}

To summarize, the possibility of calamity reduction that utilizes remote sensing for improved tsunami detection and monitoring is that digitalization shortens the time between early warning and assessment of the hazard while increasing the period for evacuation, as well as providing precise data of the area and magnitude of the calamity. By using satellite remote sensing and rapid data analysis tsunami impact and occurrence interval can be determined. According to the findings of this study, current remote sensing techniques are helping the scientific community in mapping disasters' before and after impact using real-time data and simulation to plan solutions for future natural disasters.

Remote sensing is used to increase the precision of the data as well as the speed with which it is collected and processed. The Geographic Information System (GIS) offers a framework for managing and coordinating various geospatial 


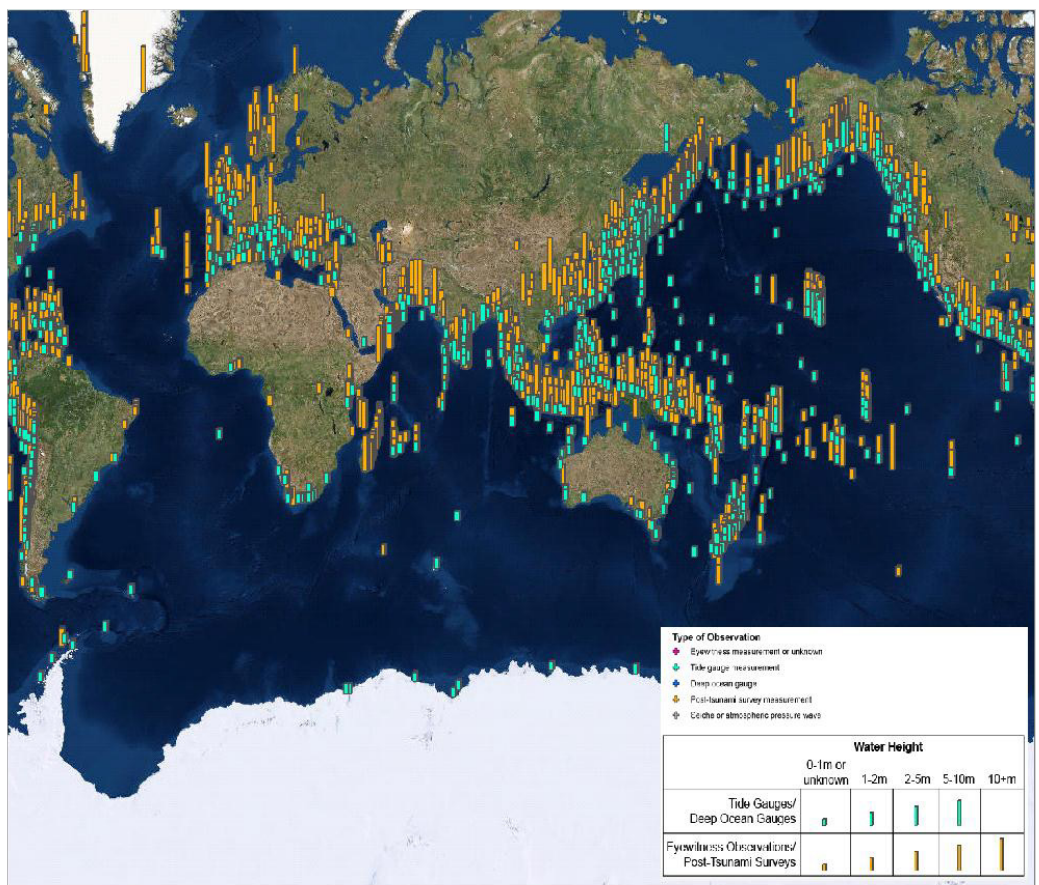

Fig. 10: Tsunami observations elaboration with vertical bars for wave height (NOAA National Centers for Environmental Information, Natural Hazards Viewer).

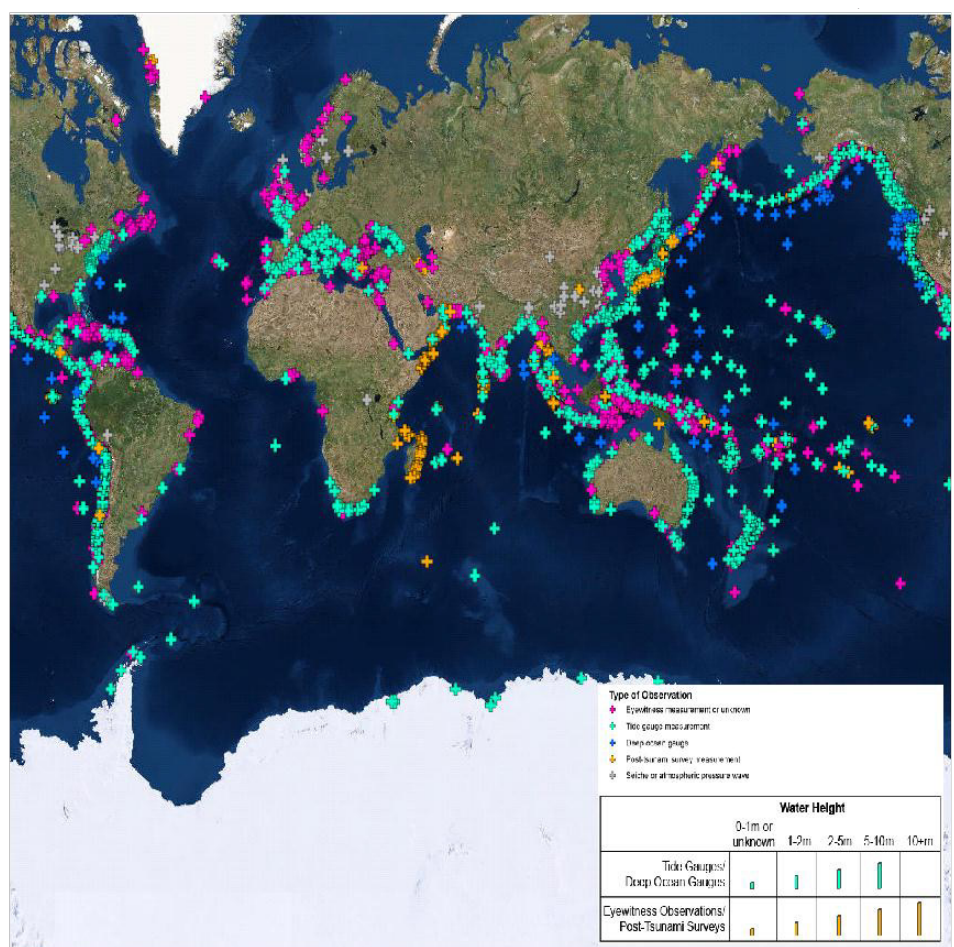

Fig. 11: Tsunami observations elaboration with color-coded by measurement type (NOAA National Centers for Environmental Information, Natural Hazards Viewer). 
Table 2: Recent Tsunami registered datasets with UTC zones (NOAA/ National Service U.S. Tsunami Warning System).

\begin{tabular}{|c|c|c|c|c|c|c|}
\hline Tsunami data Issued & Origin Time & Mag & Depth & Lat & Lon & Location \\
\hline 05-06-2019 21:25:57 & 05-06-2019 21:19:37 & 7.1 & $85 \mathrm{Mi}$. & $7^{\circ} \mathrm{S}$ & $146.4^{\circ} \mathrm{E}$ & $\begin{array}{l}\text { IN THE EASTERN NEW GUINEA RE- } \\
\text { GION, PNG }\end{array}$ \\
\hline 05-06-2019 21:25:54 & 05-06-2019 21:19:37 & 7.1 & $85 \mathrm{Mi}$. & $7^{\circ} \mathrm{S}$ & $146.4^{\circ} \mathrm{E}$ & $\begin{array}{l}\text { EASTERN NEW GUINEA REG PAPUA } \\
\text { NEW GUINEA }\end{array}$ \\
\hline 05-06-2019 21:25:42 & 05-06-2019 21:19:37 & 7.1 & $85 \mathrm{Mi}$. & $7^{\circ} \mathrm{S}$ & $146.4^{\circ} \mathrm{E}$ & $\begin{array}{l}\text { EASTERN NEW GUINEA REG PAPUA } \\
\text { NEW GUINEA }\end{array}$ \\
\hline 05-06-2019 21:25:28 & 05-06-2019 21:19:37 & 7.1 & $85 \mathrm{Mi}$. & $7^{\circ} \mathrm{S}$ & $146.4^{\circ} \mathrm{E}$ & $\begin{array}{l}\text { EASTERN NEW GUINEA REG PAPUA } \\
\text { NEW GUINEA }\end{array}$ \\
\hline 05-06-2019 21:25:05 & 05-06-2019 21:19:37 & 7.1 & $85 \mathrm{Mi}$. & $7^{\circ} \mathrm{S}$ & $146.4^{\circ} \mathrm{E}$ & $\begin{array}{l}\text { EASTERN NEW GUINEA REG PAPUA } \\
\text { NEW GUINEA }\end{array}$ \\
\hline 05-05-2019 06:51:59 & 05-05-2019 06:46:59 & 4.7 & $6 \mathrm{Mi}$ & $40.6^{\circ} \mathrm{N}$ & $127.3^{\circ} \mathrm{W}$ & 165 MILES W OF EUREKA, CALIFORNIA \\
\hline 05-02-2019 12:45:36 & 05-02-2019 12:40:17 & 4.5 & $11 \mathrm{Mi}$. & $18.1^{\circ} \mathrm{N}$ & $69.3^{\circ} \mathrm{W}$ & ABOUT 90 MILES WEST OF ISLA MONA \\
\hline 05-02-2019 01:14:58 & 05-02-2019 01:10:25 & 4.4 & $6 \mathrm{Mi}$ & $18^{\circ} \mathrm{N}$ & $65.8^{\circ} \mathrm{W}$ & VICINITY OF PUERTO RICO \\
\hline 04-29-2019 07:18:19 & 04-29-2019 07:16:08 & 4.2 & $12 \mathrm{Mi}$. & $39.3^{\circ} \mathrm{N}$ & $123.4^{\circ} \mathrm{W}$ & $\begin{array}{l}110 \text { MILES NW OF SACRAMENTO, CAL- } \\
\text { IFORNIA }\end{array}$ \\
\hline 04-28-2019 03:28:44 & 04-28-2019 03:26:01 & 4.1 & $20 \mathrm{Mi}$ & $19.3^{\circ} \mathrm{N}$ & $155.4^{\circ} \mathrm{W}$ & $\begin{array}{l}\text { IN THE SOUTHWEST RIFT ZONE OF } \\
\text { KILAUEA VOLCANO }\end{array}$ \\
\hline 04-28-2019 01:01:19 & 04-28-2019 00:58:49 & 4 & $16 \mathrm{Mi}$ & $61.4^{\circ} \mathrm{N}$ & $149.9^{\circ} \mathrm{W}$ & 30 MILES SW OF PALMER, ALASKA \\
\hline 04-23-2019 05:48:50 & 04-23-2019 05:37:57 & 6.6 & $53 \mathrm{Mi}$. & $11.9^{\circ} \mathrm{N}$ & $125.2^{\circ} \mathrm{E}$ & IN SAMAR, PHILIPPINE ISLANDS \\
\hline 04-23-2019 05:47:46 & 04-23-2019 05:37:57 & 6.6 & $53 \mathrm{Mi}$. & $11.9^{\circ} \mathrm{N}$ & $125.2^{\circ} \mathrm{E}$ & SAMAR PHILIPPINES \\
\hline 04-23-2019 05:47:25 & 04-23-2019 05:37:57 & 6.6 & $53 \mathrm{Mi}$. & $11.9^{\circ} \mathrm{N}$ & $125.2^{\circ} \mathrm{E}$ & SAMAR PHILIPPINES \\
\hline 04-23-2019 05:47:03 & 04-23-2019 05:37:57 & 6.6 & $53 \mathrm{Mi}$ & $11.9^{\circ} \mathrm{N}$ & $125.2^{\circ} \mathrm{E}$ & SAMAR PHILIPPINES \\
\hline 04-23-2019 05:46:18 & 04-23-2019 05:37:57 & 6.6 & $53 \mathrm{Mi}$ & $11.9^{\circ} \mathrm{N}$ & $125.2^{\circ} \mathrm{E}$ & SAMAR PHILIPPINES \\
\hline 04-22-2019 21:50:09 & 04-22-2019 21:44:46 & 5.4 & $7 \mathrm{Mi}$. & $50.2^{\circ} \mathrm{N}$ & $130.1^{\circ} \mathrm{W}$ & $\begin{array}{l}130 \text { MILES W OF PORT ALICE, BRITISH } \\
\text { COLUMBIA }\end{array}$ \\
\hline 04-22-2019 20:32:31 & 04-22-2019 20:27:01 & 4.6 & $2 \mathrm{Mi}$. & $50.4^{\circ} \mathrm{N}$ & $129.8^{\circ} \mathrm{W}$ & $\begin{array}{l}115 \text { MILES W OF PORT ALICE, BRITISH } \\
\text { COLUMBIA }\end{array}$ \\
\hline 04-16-2019 10:36:14 & 04-16-2019 10:29:13 & 4.1 & $12 \mathrm{Mi}$. & $19^{\circ} \mathrm{N}$ & $62.3^{\circ} \mathrm{W}$ & ABOUT 132 MILES EAST OF ANEGADA \\
\hline 04-14-2019 15:36:58 & 04-14-2019 15:30:39 & 5.6 & $26 \mathrm{Mi}$ & $51.9^{\circ} \mathrm{N}$ & $178^{\circ} \mathrm{E}$ & 50 MILES NW OF AMCHITKA, ALASKA \\
\hline 04-14-2019 03:15:53 & 04-14-2019 03:09:04 & 5.5 & $2 \mathrm{Mi}$. & $19.8^{\circ} \mathrm{N}$ & $156.1^{\circ} \mathrm{W}$ & $\begin{array}{l}\text { IN THE HUALALAI REGION OF THE BIG } \\
\text { ISLAND }\end{array}$ \\
\hline 04-12-2019 14:10:01 & 04-12-2019 14:06:27 & 5.4 & $7 \mathrm{Mi}$. & $40.4^{\circ} \mathrm{N}$ & $127^{\circ} \mathrm{W}$ & $\begin{array}{l}155 \text { MILES SW OF EUREKA, CALIFOR- } \\
\text { NIA }\end{array}$ \\
\hline 04-12-2019 12:35:04 & 04-12-2019 12:23:09 & 5.9 & $22 \mathrm{Mi}$. & $15.5^{\circ} \mathrm{S}$ & $172.5^{\circ} \mathrm{W}$ & $\begin{array}{l}\text { ABOUT } 111 \text { MILES SOUTH OF UPOLU } \\
\text { ISLAND }\end{array}$ \\
\hline 04-11-2019 19:35:48 & 04-11-2019 19:31:35 & 4 & $16 \mathrm{Mi}$. & $19^{\circ} \mathrm{N}$ & $66.8^{\circ} \mathrm{W}$ & $\begin{array}{l}\text { ABOUT } 37 \text { MILES NORTH OF PUERTO } \\
\text { RICO }\end{array}$ \\
\hline 04-09-2019 18:06:50 & 04-09-2019 17:53:57 & 6.7 & $71 \mathrm{Mi}$. & $58.7^{\circ} \mathrm{S}$ & $25.1^{\circ} \mathrm{W}$ & $\begin{array}{l}\text { IN THE SOUTH SANDWICH ISLANDS } \\
\text { REGION, SOUTH ATLANTIC OCEAN }\end{array}$ \\
\hline 04-09-2019 18:06:20 & 04-09-2019 17:53:57 & 6.7 & $71 \mathrm{Mi}$ & $58.7^{\circ} \mathrm{S}$ & $25.1^{\circ} \mathrm{W}$ & SOUTH SANDWICH ISLANDS REGION \\
\hline 04-09-2019 18:05:55 & 04-09-2019 17:53:57 & 6.7 & $71 \mathrm{Mi}$ & $58.7^{\circ} \mathrm{S}$ & $25.1^{\circ} \mathrm{W}$ & SOUTH SANDWICH ISLANDS REGION \\
\hline 04-08-2019 23:43:05 & 04-08-2019 23:30:44 & 4.4 & $65 \mathrm{Mi}$. & $19^{\circ} \mathrm{N}$ & $69.8^{\circ} \mathrm{W}$ & $\begin{array}{l}\text { ABOUT } 135 \text { MILES NORTHWEST OF } \\
\text { ISLA MONA }\end{array}$ \\
\hline 04-08-2019 23:36:39 & 04-08-2019 23:30:44 & 4.4 & $16 \mathrm{Mi}$. & $19.1^{\circ} \mathrm{N}$ & $69.7^{\circ} \mathrm{W}$ & $\begin{array}{l}\text { ABOUT } 135 \text { MILES NORTHWEST OF } \\
\text { ISLA MONA }\end{array}$ \\
\hline
\end{tabular}




\begin{tabular}{|c|c|c|c|c|c|c|}
\hline Tsunami data Issued & Origin Time & Mag & Depth & Lat & Lon & Location \\
\hline 04-08-2019 20:01:33 & 04-08-2019 19:57:43 & 4.6 & $12 \mathrm{Mi}$. & $56.4^{\circ} \mathrm{N}$ & $149.3^{\circ} \mathrm{W}$ & 155 MILES SE OF KODIAK CITY, ALASKA \\
\hline 04-07-2019 03:04:17 & 04-07-2019 02:59:58 & 4.6 & $10 \mathrm{Mi}$. & $56.3^{\circ} \mathrm{N}$ & $154.4^{\circ} \mathrm{W}$ & $\begin{array}{l}130 \text { MILES SW OF KODIAK CITY, ALAS- } \\
\text { KA }\end{array}$ \\
\hline 04-05-2019 16:25:23 & 04-05-2019 16:14:20 & 6.6 & $38 \mathrm{Mi}$. & $55.5^{\circ} \mathrm{S}$ & $27.7^{\circ} \mathrm{W}$ & $\begin{array}{l}\text { IN THE SOUTH SANDWICH ISLANDS } \\
\text { REGION, SOUTH ATLANTIC OCEAN }\end{array}$ \\
\hline 04-05-2019 16:24:03 & 04-05-2019 16:14:20 & 6.6 & $38 \mathrm{Mi}$. & $55.5^{\circ} \mathrm{S}$ & $27.7^{\circ} \mathrm{W}$ & SOUTH SANDWICH ISLANDS REGION \\
\hline 04-05-2019 16:23:39 & 04-05-2019 16:14:20 & 6.6 & $38 \mathrm{Mi}$. & $55.5^{\circ} \mathrm{S}$ & $27.7^{\circ} \mathrm{W}$ & SOUTH SANDWICH ISLANDS REGION \\
\hline 04-05-2019 16:22:50 & 04-05-2019 16:14:20 & 6.4 & $58 \mathrm{Mi}$. & $55.9^{\circ} \mathrm{S}$ & $27.9^{\circ} \mathrm{W}$ & $\begin{array}{l}\text { IN THE SOUTH SANDWICH ISLANDS } \\
\text { REGION, SOUTH ATLANTIC OCEAN }\end{array}$ \\
\hline 04-02-2019 21:47:46 & 04-02-2019 21:36:00 & 6.5 & $19 \mathrm{Mi}$. & $52^{\circ} \mathrm{N}$ & $178^{\circ} \mathrm{E}$ & $\begin{array}{l}\text { RAT ISLANDS ALEUTIAN ISLANDS } \\
\text { ALASKA }\end{array}$ \\
\hline 04-02-2019 21:47:28 & 04-02-2019 21:36:00 & 6.5 & $19 \mathrm{Mi}$. & $52^{\circ} \mathrm{N}$ & $178^{\circ} \mathrm{E}$ & $\begin{array}{l}\text { RAT ISLANDS ALEUTIAN ISLANDS } \\
\text { ALASKA }\end{array}$ \\
\hline 04-02-2019 21:47:12 & 04-02-2019 21:36:00 & 6.5 & $19 \mathrm{Mi}$. & $52^{\circ} \mathrm{N}$ & $178^{\circ} \mathrm{E}$ & $\begin{array}{l}\text { RAT ISLANDS ALEUTIAN ISLANDS } \\
\text { ALASKA }\end{array}$ \\
\hline 04-02-2019 21:46:49 & 04-02-2019 21:36:00 & 6.5 & $19 \mathrm{Mi}$. & $52^{\circ} \mathrm{N}$ & $178^{\circ} \mathrm{E}$ & $\begin{array}{l}\text { RAT ISLANDS ALEUTIAN ISLANDS } \\
\text { ALASKA }\end{array}$ \\
\hline 04-02-2019 21:45:00 & 04-02-2019 21:36:00 & 6.5 & $19 \mathrm{Mi}$. & $52^{\circ} \mathrm{N}$ & $178^{\circ} \mathrm{E}$ & 55 MILES NW OF AMCHITKA, ALASKA \\
\hline
\end{tabular}

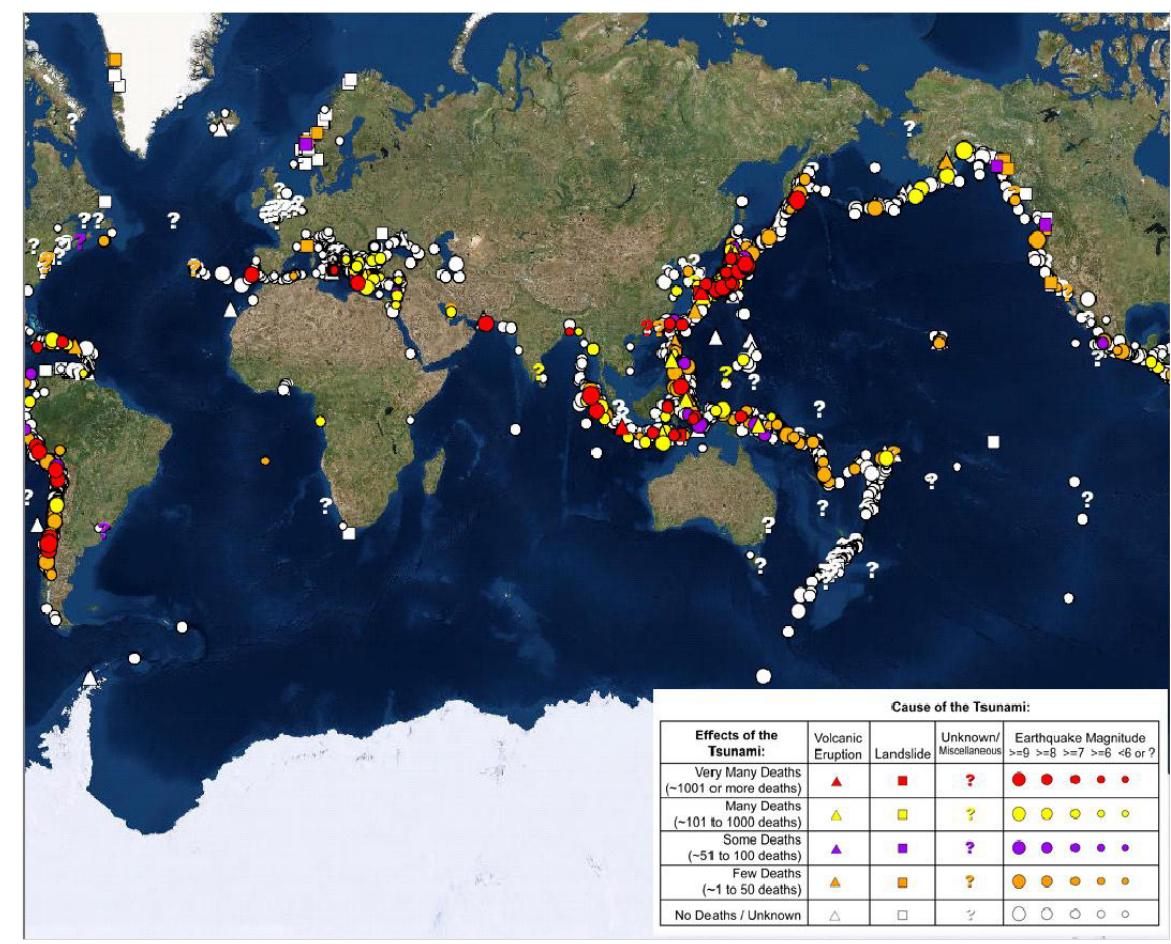

Fig. 12: Tsunami events elaboration with symbols for cause or fatalities (NOAA National Centers for Environmental Information, Natural Hazards Viewer). 
information, and it is used to execute its functionalities with different modules. A Geographic Information System is used to manage remote sensing information to separate application data for analysis. Globally, many comparison studies have been conducted using remote sensing techniques, and reports have been issued to inform various government bodies to take immediate action. Operational considerations for tsunami modeling and a number of current operational models are introduced in this study.

\section{ACKNOWLEDGEMENT}

The author would like to thank UPES Dehradun for facilitating the space to carry out the research work. The corresponding author thanks Mr. Saikat Banerjee, CubicX India for the great support in terms of the data processing and analysis. Also, thankful to Dr. Surya Prakash Tiwari, Assistant Professor, King Fahad University of Petroleum \& Minerals for the continuous help in the improvement of this paper.

\section{REFERENCES}

Arii, M., Koiwa, M. and Aoki, Y., 2014. Applicability of SAR to marine debris surveillance after the great east Japan earthquake. IEEE JSTARS, 7(5): 729-1744.

Bryant, E. 2001. Tsunami: The Underrated Hazard. Cambridge University Press, New York.

Craig, W. and Sulem, C. 1993. Numerical simulation of gravity waves. J. Comp. Phy., 108: 73-83.

Chatterjee, B., Porwal, M.C. and Hussain, Y.A., 2008. Assessment of tsunami damage to the mangrove in India using remote sensing and GIS. Int. Soc. Photogramm. Remote Sens., 45: 283-288.

Chaturvedi, S.K., Guven, U. and Srivastava, P.K., 2016.Measurement of tsunami wave Eigenfunctions in deep, intermediate, and shallower regions. Curr. Sci., 11(12): 750-756.

Chaturvedi, S.K., Srivastava, P.K. and Guven, U. 2017. A brief review on tsunami early warning detection using the BPR approach and post-analysis by SAR satellite dataset. J. Ocean Eng. Sci., 2(2): 83-89.

Chaturvedi, S.K. 2019. A case study of the tsunami detection system and ocean wave imaging mechanism using radar. J. Ocean Eng. Sci., 4(3): 203-210.

Chaturvedi, S.K., Guven, U. and Srivastava, P.K. 2020. Measurement and validation of tsunami Eigenvalues for the various water wave conditions. J. Ocean Eng. Sci., 05(01), 41-54

Dean, R.G. and Dalrymple, M. 1984. Water waves and mechanics for engineers and scientists, Prentice-Hall, Inc., Englewood Cliffs.

Dean, R.G., 1986. Evaluation and development of water wave theories for engineering applications. Presentation of Research Results. Florida Univ. Gainesville C.
Eze, C.L and Uko, D.E. 2000. Mathematical evaluation of tsunami propagation. J. Appl. Sci., 4: 213-216.

Filloux, J. H. 1970. Bourdon Tube Deep Sea Tide Gauges in Tsunamis in the Pacific Ocean. Honolulu University Press, Hawai, USA, pp. 223-238.

Geist, E.L. 1998. Local tsunamis and earthquake source parameters. Adv. Geophys., 39:117-209.

Helm, A. and Stosius, R., 2007. Status of GNSS reflectometry-related receiver developments and feasibility studies within the German Indonesian tsunami early warning system. Int. Geosci. Remote Sens., 116(54): 5084-5087.

Josheph, A. 2010. Tsunamis: Detection, Monitoring, and Early-warning technologies. Report by National Institute of Oceanography, India.

Kânoglu,U. and Synolakis, C.E. 1998. Longwave run-up on piecewise linear topographies. J. Fluid Mech., 374: 1-28.

Lin, F.C., Sookhanaphibarn, K. and Pararas-Carayannis, G. 2013. REMOTE: Reconnaissance \& monitoring of tsunami events. Sci. Tsunami Hazards, 33(2): 86-111.

Liu, P.L., Cho, Y.S. and Briggs, M.J. 1995. Run-up of solitary waves on a circular island. J. Fluid Mech., 302: 259-285.

Madsen, P.A. and Schäffer, H.A., 2010. Analytical solution for tsunami runup on a plane beach: single waves, $\mathrm{N}$-waves and transient waves. J. Fluid Mech., 645: 27-57.

Martino, L., Ulivieri, C., Jahjah, M. and Loret. E., 2009. Remote sensing and GIS techniques for natural disaster monitoring, In Philip, O. (ed), Space Technologies for the Benefit of Human Society and Earth. Springer, New York, pp. 331-382.

Murty, T.S., Rao, A.D. and Nistor, I., 2006. Numerical modeling concepts for tsunami warning systems. Curr. Sci., 90(8): 1073-1081.

Okal, E.A. 1988. Seismic parameters controlling far-field tsunami amplitudes: A review. Natural Hazards, 28: 67-96.

Prins, J.E. 1958. Characteristics of waves generated by local disturbance. AGU, 39: 865-874.

Sirikulchayanon, P., Sun, W. and Oyana, T.J. 2005. Assessing the impact of the 2004 tsunami on mangroves using remote sensing and GIS techniques. Int. J. Remote Sens., 29(12): 3553-3576.

Tadepalli, S. and Synolakis, C.E. 1994.The run-up of N-waves on sloping beaches. Proc. of Royal Soc. London, 445: 99-112.

Tadepalli, S. and Synolakis, C.E. 1996. Model for the leading waves of tsunamis. Phys. Rev. Lett., 77(10): 2141-2144.

Titov, V.V. 2000. Tsunami Forecasting. In Bernard, E.N. and Robinson, A.R. (eds.), The. Sea. Vol. 15. Harvard University Press, Cambridge, pp. 371-400.

Todorovska, M.I. and Trifunac, M.D., 2001.Generation of tsunamis by a slowly spreading uplift of the seafloor. Soil Dyn. Earthquake Eng., 21: 151-167.

Westen, V. and Soeters, R. 2009. Remote sensing and geographic information systems for natural disaster management presented at natural disasters and their mitigation: A Remote Sensing and GIS Perspective. Indian Inst. Remote Sensi., 16: 31-76.

Ward, S.N. 1980. Relationships of tsunami generation and earthquake source. J. Phys. Earth Sci., 28: 441-474.

Zielinski, A. and Saxena,N. 1983. The rationale for measurement of midocean tsunami signature. Marine Geodesy, 6: 331-337. 